\title{
İmmün Yetmezlikli Hastalardan Elde Edilen Sitomegalovirüs İzolatlarındaki Gansiklovir Direncinin Araştırılması
}

\author{
Investigation of Ganciclovir Resistance in Cytomegalovirus \\ Strains Obtained from Immunocompromised Patients
}

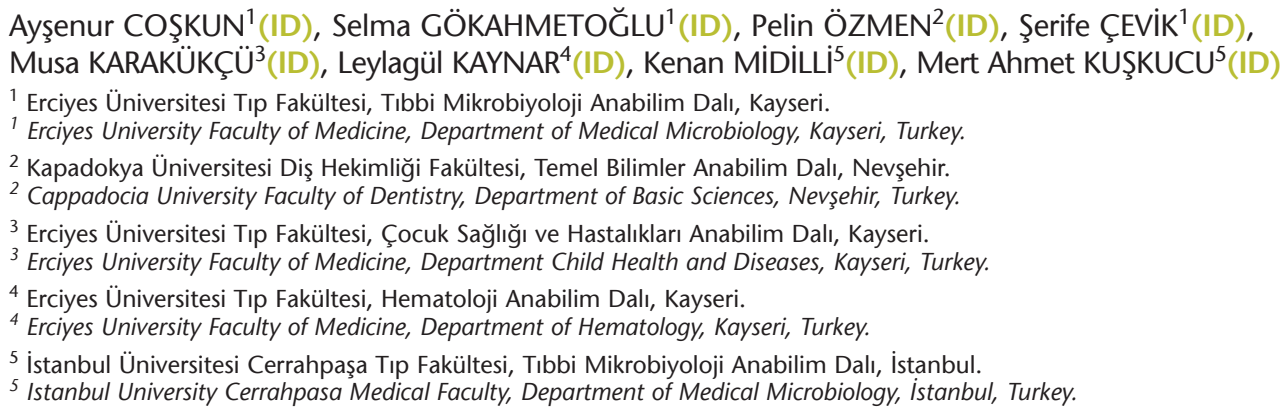

Makale Atıfı: Coşkun A, Gökahmetoğlu S, Özmen P, Çevik Ş, Karakükçü M, Kaynar L ve ark. Immün yetmezlikli hastalardan elde edilen sitomegalovirüs izolatlarındaki gansiklovir direncinin araştırılması. Mikrobiyol Bul 2020;54(4):619-628.

\section{ÖZ}

Sitomegalovirüs (CMV), sağlıkı bireylerde asemptomatik seyreden ancak transplantasyon hastaları ve kazanılmış immün yetmezlik sendromlu (AIDS) hasta gruplarında ciddi mortalite ve morbiditeye sebep olan bir virüstür. Gansiklovir (GCV), CMV'ye bağlı enfeksiyonlarda morbidite ve mortaliteyi belirgin bir şekilde azaltan ve tedavide ilk tercih olarak kullanılan bir nükleozit analoğudur. GCV, insanda CMV hastalığının tedavisinde etkinliği gösterilmiş ilk ilaç olup, aynı zamanda asiklovirle homologtur. CMV hastalığını önlemek veya tedavi etmek için uzun süreli antiviral tedavi gereklidir, ancak bu durum direnç gelişimini beraberinde getirmektedir. CMV'de görülen antiviral direnç oranı \%8-14 olarak bildirilmektedir. CMV izolatlarında GCV direnci en sık olarak UL97 kinaz gen bölgesinde görülmektedir. Bu çalışmada, immün yetmezliği olan hastalardan elde edilen CMV izolatlarında GCV direncinin araştııııması amaçlanmıştır. Hematoloji servisinde takip edilen 20 çocuk, 29 erişkin toplam 49 hasta çalışmaya dahil edilmiştir. CMV DNA viral yükü $\geq 10^{3} \mathrm{kopya} / \mathrm{ml}$ olan 49 hastadan elde edilen 53 örnek GCV direnci yönünden incelenmiştir. Çalışmada UL97 gen bölgesinin, 674 baz çifti (bp) büyüklüğündeki kısmında 3500 Abi Prism Genetik Analiz cihazı (Applied Biosystems, Thermo Fisher Scientific, ABD) kullanılarak yapılan Sanger dizi analizi yöntemiyle DNA dizileri belirlenmiştir. Bu yöntemle değerlendirilemeyen örneklere yeni nesil dizileme (NGS) yöntemi uygulanmıştır. Sanger yöntemi ile 53 örneğin 35 (\%66)'inde GCV direnci saptanmamıştır. Üç hastada ise C592G, C607S ve M460I GCV direnç mutasyonu tespit edilmiştir. Diziler karışık olduğundan, 15 örnekte Sanger ile direnç değerlendirilememiş ve NGS ile çalışılan bu örneklerde direnç 
saptanmamıştır. Toplam 49 hastanın 3 (\%6.1)'ünde antiviral direnç mutasyonu saptanmıştır. Çalışmaya dahil edilen 20 hastada, literatürde bildirilen ve fenotipik testlerle ilaçlara duyarlı olduğu belirlenen üç varyant sekans (A442G, C592F, A427V) ile literatürde bildirilmeyen 78 varyant sekans saptanmıştır. Sonuç olarak, antiviral direnç saptanması hastaların takibinde önemli olup, tedavinin planlanmasında klinisyeni yönlendirmektedir. Sanger yöntemi ile değerlendirilemeyen örneklerin NGS ile çalışılması gerektiği ve ilk defa saptanan varyant sekansların ilaç direncindeki rolünün belirlenmesi için daha ileri çalışmalara ihtiyaç olduğu sonucuna varılmıştır.

Anahtar kelimeler: Antiviral direnç; gansiklovir; Sitomegalovirüs; dizi analizi; mutasyon.

\section{ABSTRACT}

$\mathrm{CMV}$ is a virus that is asymptomatic in healthy individuals but can cause serious mortality and morbidity in transplant patients and patients with acquired immunodeficiency syndrome (AIDS). Ganciclovir (GCV) is a nucleoside analog that significantly reduces morbidity and mortality in CMV-related infections and is used as the first choice in treatment. It is the first drug shown to be effective in the treatment of CMV disease in humans, and is also homologous to acyclovir. Long-term antiviral therapy is required to prevent or treat CMV disease, but this can cause antiviral resistance which was reported to be $8-14 \%$ in CMV. In CMV strains, GCV resistance is most common in the UL97 kinase gene region. The aim of this study was to investigate GCV resistance in CMV strains obtained from the patients with immune deficiency. A total of 49 patients, including 20 children, 29 adults, who were followed in the department of hematology were included in the study. Fifty-three samples from 49 patients with CMV DNA viral load $\geq 10^{3}$ copies $/ \mathrm{ml}$ were examined for GCV resistance. In the study, DNA sequences were determined by Sanger sequence analysis method 3500 Abi Prism Genetic Analyser (Applied Biosystems, Thermo Fisher Scientific, USA) in the 674 bp part of the UL97 gene region. The next generation sequencing (NGS) method was applied to the samples that could not be evaluated with this method. GCV resistance was not detected in 35 (66\%) of 53 samples with the Sanger method. C592G, C607S and M460I GCV resistance mutation was detected in three patients. Since the sequences were mixed, resistance analysis could not be evaluated with Sanger in 15 patient samples and the resistance was not detected in these samples studied with NGS. Antiviral resistance mutation was detected in three of 49 patients $(6.1 \%)$. In 20 patients included in the study, three variant sequences (A442G, C592F, A427V) reported in the literature and determined to be sensitive to drugs by phenotypic tests and 78 variant sequences that were not reported in the literature were detected. As a result, the detection of antiviral resistance is important in the follow-up of the patients and guides the clinician in planning of the treatment. It was concluded that the samples that could not be evaluated with the Sanger method should be studied with NGS and further studies are needed to determine the role of the variant sequences detected for the first time in drug resistance.

Keywords: Antiviral resistance; ganciclovir; Cytomegalovirus; sequence analysis; mutation.

\section{Gíriş}

Sitomegalovirüs (CMV), immün sistemi normal kişilerde genellikle asemptomatik hastalık oluştururken, transplantasyon hastaları ve kazanılmış immün yetmezlik sendromlu (AIDS) olgular gibi bağışıklığı baskılanmış hasta gruplarında ciddi mortalite ve morbiditeye neden olmaktadır.

CMV hastalığının profilaksi ve tedavisi için kullanılan, Amerika Birleşik Devletleri’nde "Food and Drug Administration (FDA)" onayı almış viral DNA polimeraz inhibitörü olan antiviral ajanlar; valasiklovir, gansiklovir (GCV), valgansiklovir, foskarnet (FOS) ve sidofovirdir ${ }^{1}$. 
GCV, CMV'ye bağlı enfeksiyonlarda morbidite ve mortaliteyi belirgin bir şekilde azaltan ve tedavide ilk tercih olarak kullanılan bir nükleozit analoğudur. Insanda CMV hastaı̆̆ının tedavisinde etkinliği gösterilmiş ilk ilaç olup, aynı zamanda asiklovirle homologtur. Antiviral aktivite için spesifik bir viral enzim tarafından fosforilasyona ihtiyaç duymaktadır. CMV'nin UL97 geninin fosfotransferaz üretimi GCV'yi, GCV monofosfata dönüştürmektedir. Monofosfat, hücresel enzim yoluyla trifosfata fosforile edilmektedir. GCV trifosfat, CMV DNA polimeraz enziminin güçlü bir inhibitörüdür² ${ }^{2}$.

CMV hastalığını önlemek veya tedavi etmek için uzun süreli antiviral tedavi gereklidir, ancak bu durum direnç gelişimini de beraberinde getirmektedir. CMV'de görülen antiviral direnç oranı \%8-14 olarak bildirilmektedir ${ }^{3}$. Antiviral ilaçlara direnç, genellikle birkaç hafta antiviral tedaviden sonra ortaya çıkar. Yükselen CMV antijenemi veya DNA seviyeleri veya CMV hastalığı semptomlarının ilerlemesi klinik veya viral dirence işaret etmektedir. Klinik direnç konakçı faktörlere, viral direnç ise viral genomdaki mutasyonlara bağlıdır ${ }^{4}$.

CMV'nin antiviral ajanlara duyarlılığını test etmek için fenotipik ve genotipik testler uygulanmaktadır. Genotipik testler fenotipik testler ile karşılaştırıldığında daha ucuz ve hızlı sonuç verirler, ancak seçilen hedef dışındaki mutasyonları saptayamazlar. Dizi analizine dayanan genotipik yöntemlerde saptanan direnç mutasyonlarının doğrulanması fenotipik yöntemlerle gerçekleşmektedir ${ }^{1}$.

CMV'de GCV direnci en sık UL97 gen bölgesinde görülmektedir. CMV'de GCV direnci sıklıkla DNA dizi analizi yöntemi ile araştırılmaktadır. Bu çalışmada, immün yetmezliği olan hastalardan elde edilen CMV izolatlarında GCV direncinin araştırılması amaçlanmıştır.

\section{GEREÇ ve YÖNTEM}

Bu çalışma, Erciyes Üniversitesi Klinik Araştırmalar Etik Kurulu onayı ile gerçekleştirildi (Tarih: 22.01.2016 ve Karar no: 2016/57).

\section{Hastalar ve Örnekler}

Ocak 2016-Eylül 2017 tarihleri arasında erişkin ve pediatrik hematoloji kliniklerinde takip edilen hastalara ait örneklerden CMV DNA'sı $\geq 10^{3}$ kopya/ml olanlar çalışmaya alındı. Çalışmaya 20'si çocuk, 29'u erişkin 49 hastaya ait 53 plazma örneği dahil edildi.

Hastaların 21 (\%42.9)'i erkek, 28 (\%57.1)'i kadın olup, çalışmaya dahil edilen 49 hastanın 41'i kemik iliği transplant (KIT) alıcısı, sekizi ise hematoloji poliklinikleri/servislerinde takip edilen (transplantasyon yapılmamış) hastalardı. KiT alıcılarının 34'üne allojenik kemik iliği transplantasyonu (AKiT), yedisine otolog kemik iliği transplantasyonu (OKIT) yapılmıştı.

\section{GCV Direncinin Araştırılması}

Çalışma, UL97 gen bölgesinde, 3500 Abi Prism Genetik Analiz cihazı (Applied Biosystems, Thermo Fisher Scientific, ABD) kullanılarak yapılan Sanger dizi analizi yöntemiyle yapıldı. Örneklerden DNA izolasyonu (EZ1 Advanced, Qiagen-Almanya) yapıldıktan sonra, CMV GCV direnci için UL97 gen bölgesindeki 674 baz çifti (bp) büyüklüğündeki bölge polimeraz zincir reaksiyonu (PCR) ile çoğaltıldı. PCR primerleri olarak, Primer 1; 
5'-GCA CAA CGT CAC GGT ACA TC-'3 ve Primer 2; 5'-ACA TCT TGG CCT CCA CAA AG'3 kullanıldı. Aktivasyon basamağı, $95^{\circ} \mathrm{C}^{\prime}$ de 15 dakika olarak belirlendi. Isı döngü cihazı 45 döngüye programlanarak $94^{\circ} \mathrm{C}^{\prime}$ de 30 saniye denatürasyon, $55^{\circ} \mathrm{C}^{\prime}$ de 30 saniye primer bağlanması ve $72^{\circ} \mathrm{C}^{\prime}$ de 30 saniye amplifikasyon şeklinde çalışıldı. Son uzama işlemi, $72^{\circ} \mathrm{C}^{\prime}$ de 10 dakika olarak tamamlandı. Elde edilen amplikonlar agaroz jel elektroforezinde görüntülenerek, Sanger dizi analizi işlemine alındı. Örneklerden elde edilen dizilerde, literatürde bildirilen CMV GCV direnç mutasyonlarının sıklıkla bulunduğu UL97 protein kinaz genindeki 420-664 kodonlarını kapsayan DNA dizileri değerlendirildi.

Dizileri değerlendirmek için dizi analiz verilerinin hızlı bir şekilde yorumlanmasını sağlayan, hastaların CMV UL97 dizilerinin yüklendiği ve daha sonra vahşi tip sekansa sahip ilaca duyarlı HCMV suşuyla (TB40-BAC4) karşılaştıııldığı çevrim içi mutasyon analiz sistemi kullanıldı (www.informatik.uni-Im.de/ni/staff/Hkestler/hcmv/). Daha sonra, UL97 vahşi tip sekansını ve verilen UL97 nükleotit dizi analizini hizalamak için BLASTX (versiyon: NCBI BLAST 2.2.18) programı kullanılarak, mutasyon lokasyonlarına ve mutasyona uğramış amino asitlere göre, sistem mutasyonları HCMV mutasyon veri tabanı ile karşılaştırıldı. Verilen HCMV sekansında hangi tip mutasyonların olduğu bildirildi. Sanger dizi analizi ile değerlendirilemeyen örnekler, hizmet alımı yapılarak yeni nesil dizileme (NGS) yöntemi ile araştırıldı.

\section{BULGULAR}

Çalışmaya dahil edilen 49 hastadan elde edilen 53 örneğin 35 (\%66)'inde GCV direnci saptanmamıştır. Antiviral direnç saptanan 3 (\%6.1) hastanın birinde C592G, diğerinde C670S, diğerinde ise M460I mutasyonu bulunmuştur. Sanger yöntemi ile 15 hasta örneğinde diziler karışık olduğu için direnç analizi değerlendirilememiştir. NGS yapılan bu hastalarda GCV direnci saptanmamıştır.

Direnç saptanan hastalardan ikisinin erişkin, birinin çocuk olduğu belirlenmiştir. Çocuk hastaların hepsi transplant alıcısı olup, toplam 20 hastanın 1 (\%5)'inde GCV direnç mutasyonu (C592G) tespit edilmiştir.

Transplantasyon yapılan 41 hastanın 21'i erişkin olup, bu hastaların 1 (\%4.8)'inde M460I GCV direnç mutasyonu saptanmıştır. Çalışmaya dahil edilen 49 hastanın sekizi hematoloji poliklinik ve servislerinde takip edilen transplantasyon yapılmamış hastalar olup, 1 (\%12.5) hastada C607S mutasyonu bulunmuştur.

Antiviral direnç mutasyonu, farklı zamanlarda laboratuvara gönderilen hasta örneklerinden retrospektif olarak çalışılmıştır.

GCV direnç mutasyonu (C592G) tespit edilen birinci hasta, pediatrik AKiT alıcısı olup, transplantasyonun 17. gününde CMV viral yükünün $6.080 \mathrm{IU} / \mathrm{ml}$ olması üzerine bir haftalık FOS tedavisi başlanmış, viral yükün $32.000 \mathrm{IU} / \mathrm{ml}$ değerine ulaşmasıyla 164 günlük GCV tedavisi başlanmıştır. Hastanın CMV DNA düzeylerinin günlere ve uygulanan antiviral ilaçlara göre değişimi Şekil 1'de izlenmektedir. Hastada viral yükün $18.000 \mathrm{IU} / \mathrm{ml}$ olarak saptandığı örnekten GCV direnç mutasyonu çalışılmış ve C592G mutasyonu saptanmıştır (Şekil 2). 


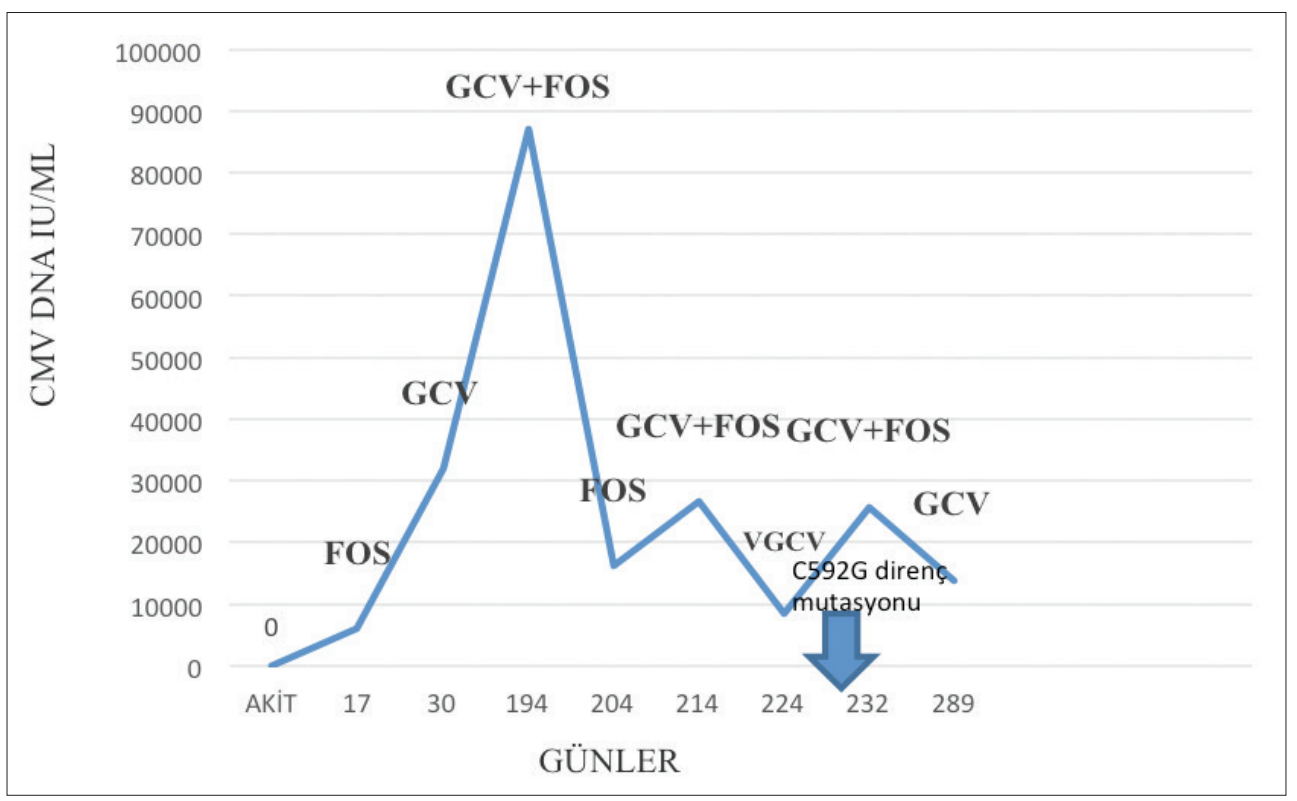

Şekil 1. CMV GCV C592G mutasyonu saptanan birinci hastanın günlere göre CMV DNA düzeyleri ve aldığı antiviral ilaçlar.

GCV: Gansiklovir, FOS: Foskarnet.

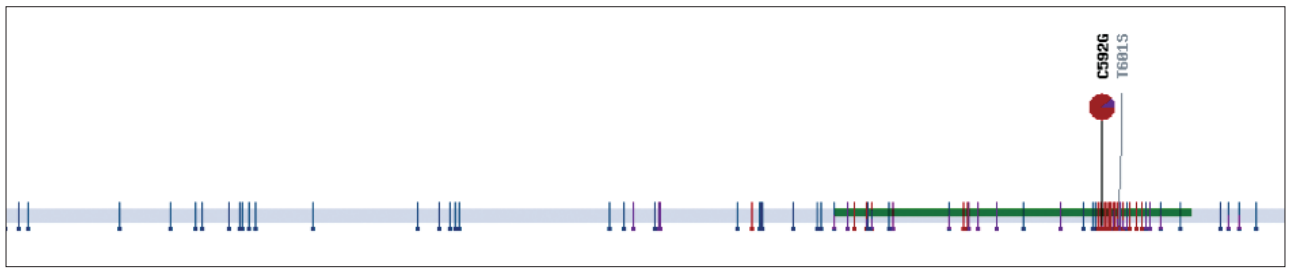

Şekil 2. Birinci hastanın CMV UL97 gen bölgesinin dizi analizi sonucunda saptanan C592G mutasyonu.

Akut miyeloid lösemi (AML) tanısı nedeni ile bir buçuk yıl arayla iki kez haploidentik KiT yapılan ikinci hastanın, ikinci transplantasyondan önceki 12. günde CMV DNA'sı 592 IU/ml olarak saptanmış ve hastaya GCV tedavisi başlanmış, tedaviyi takip eden dördüncü günde CMV viral yük $842 \mathrm{IU} / \mathrm{ml}^{\prime}$ ye ulaşmıştır. Hastanın transplantasyon sonrası aldığı antiviral ilaçlar ve CMV DNA düzeyleri Şekil 3'te gösterilmiştir. Transplantasyonun beşinci gününde CMV DNA 1.444 IU/ml'dir. Bu örnekte, Sanger yöntemiyle M460I GCV direnç mutasyonu saptanmıştır (Şekil 4). Transplantasyonun onuncu gününde CMV DNA 1.536 IU/ml olarak bulunduğundan, GCV tedavisine yeniden başlanmıştır. Transplantasyondan 20 gün sonra CMV viral yükü < $130 \mathrm{IU} / \mathrm{ml}$ olarak bulunmuş, üçüncü AKiT uygulanmasının ardından düşük pozitiflik devam etmiştir. Ancak, genel durumun kötüye gitmesiyle üçüncü transplantasyonun 12. gününde hasta kaybedilmiştir.

CMV GCV direnç mutasyonu (C607S) bulunan üçüncü hasta lenfoma tanısı alan kadın hasta olup, bu hastaya transplantasyon yapılmamıştır. Hastanın CMV DNA viral yükü 


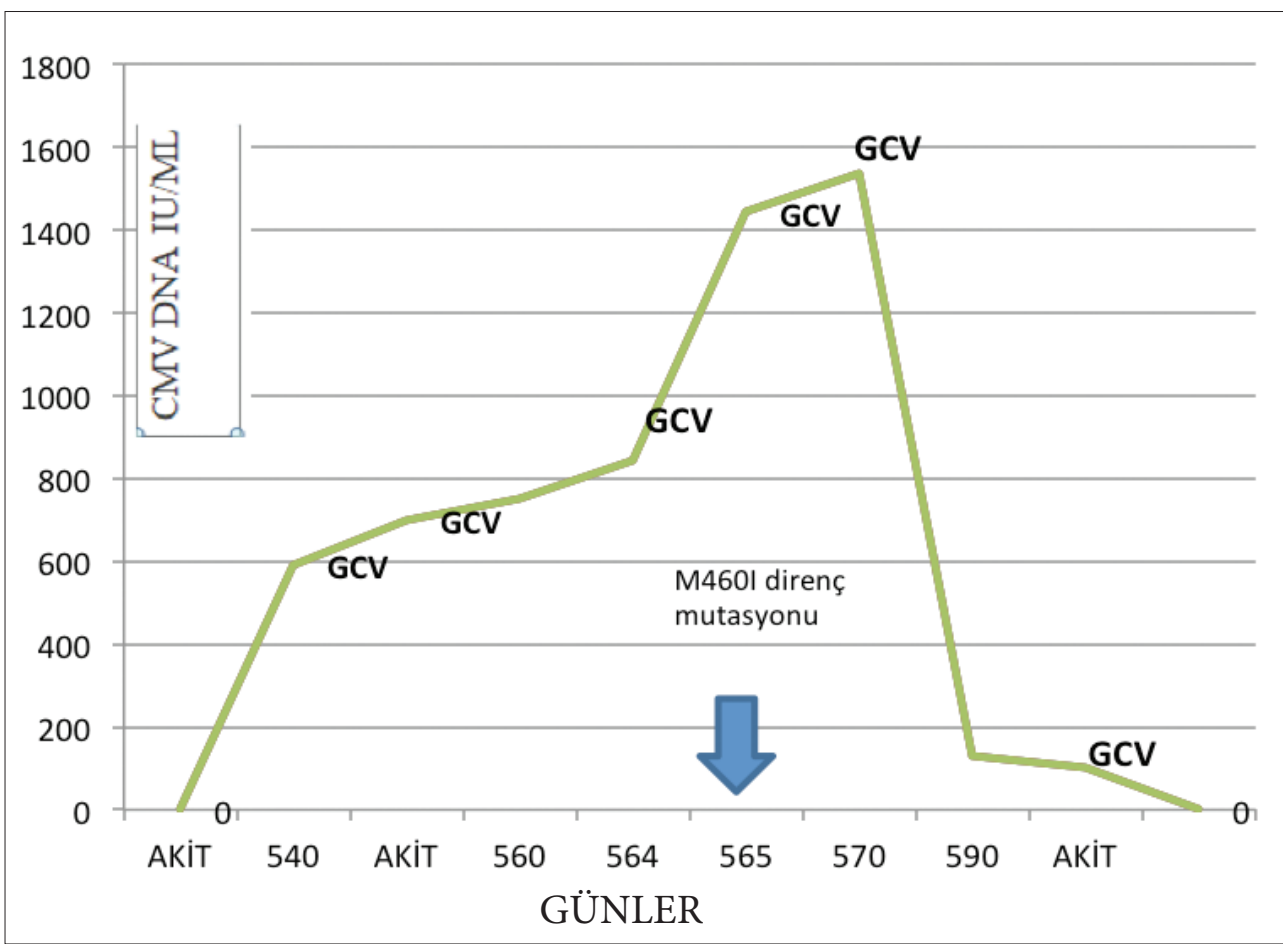

Şekil 3. CMV GCV M460I mutasyonu saptanan ikinci hastanın günlere göre CMV DNA düzeyleri ve aldığı antiviral ilaçlar.

GCV: Gansiklovir.

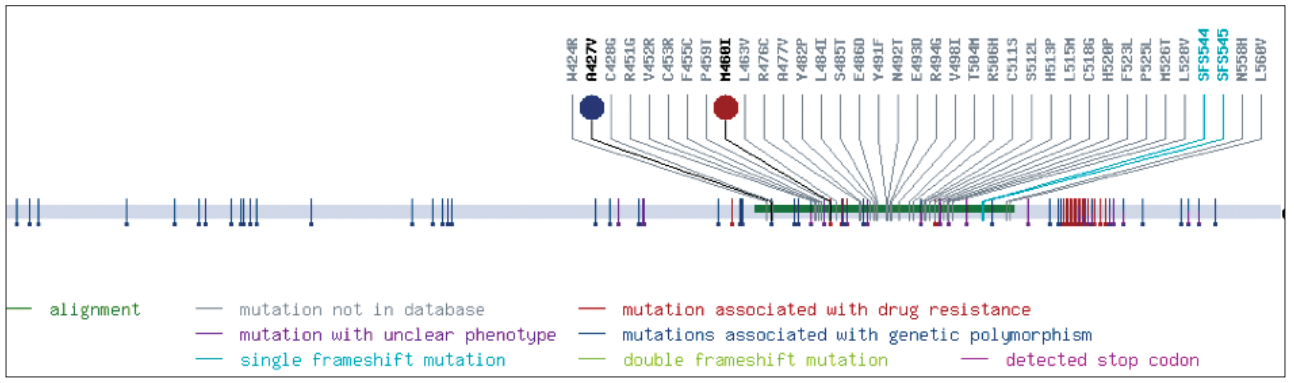

Şekil 4. Ikinci hastanın, CMV UL97 gen bölgesinde saptanan M460I mutasyonu ve varyant diziler.

kemoterapi başlangıcından 25 gün sonra yükselmeye başlamış ve 25. günde 866.631 $\mathrm{IU} / \mathrm{ml}$ olarak bulunduğundan GCV başlanmıştır. Viral yükün $15.570 \mathrm{IU} / \mathrm{ml}$ ye gerilemesinden dolayı GCV tedavisi kesilse de iki hafta sonra CMV DNA 200.052 IU/ml'ye yükselmiştir. Hastanın günlere göre CMV DNA düzeyleri ve aldığı antiviral ilaçlar Şekil 5'te belirtilmiş olup, CMV UL97 gen bölgesinde C607S GCV direnç mutasyonu bulunmuştur (Şekil 6). 


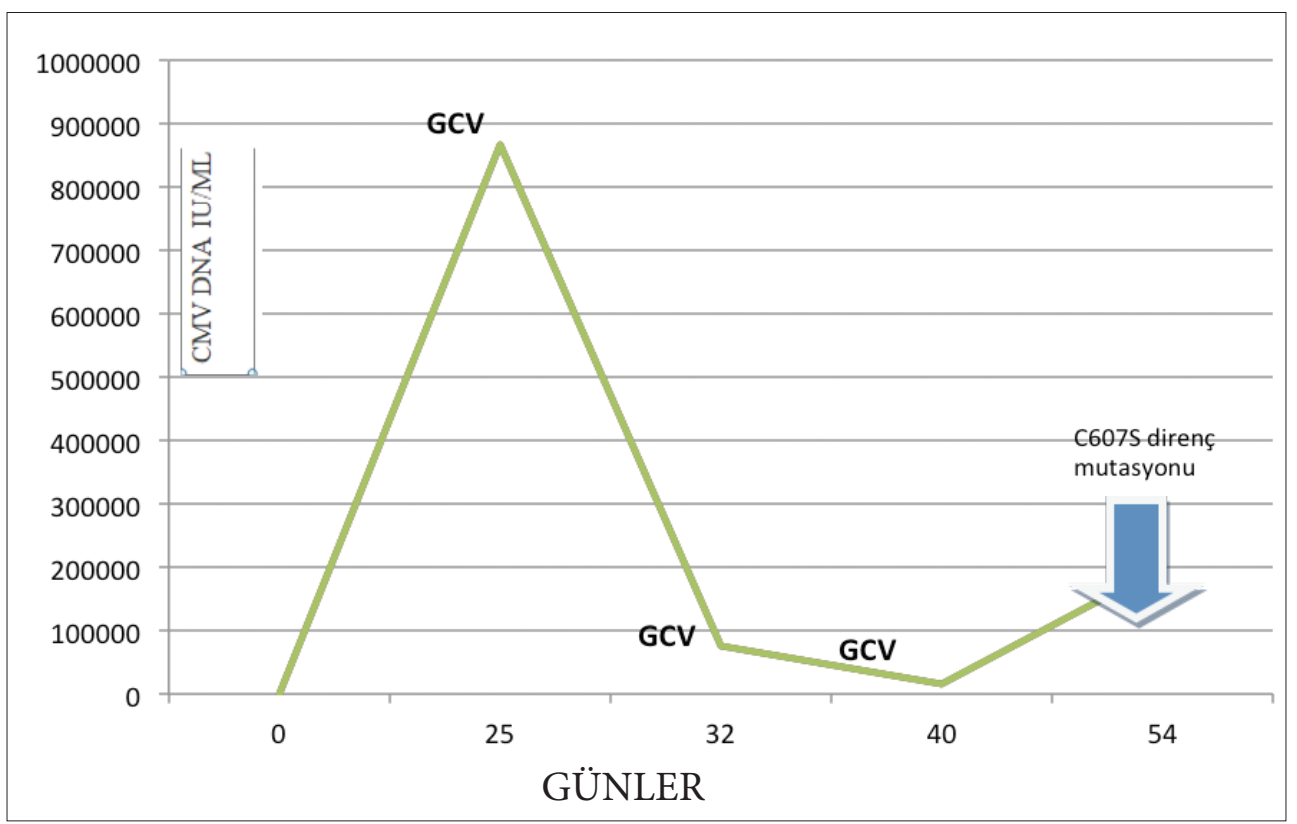

Şekil 5. Üçüncü hastanın günlere göre CMV DNA düzeyleri ve aldığı antiviral ilaçlar. GCV: Gansiklovir.

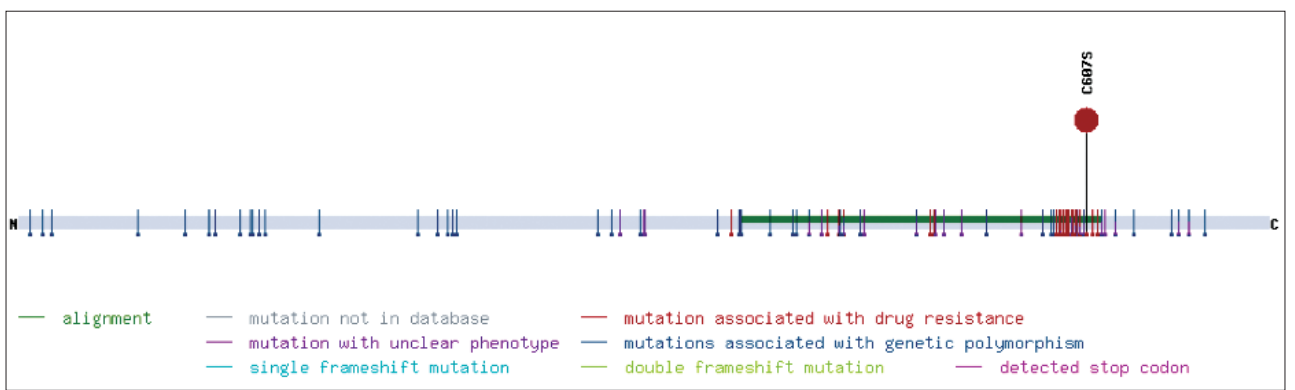

Şekil 6. Üçüncü hastanın, CMV UL97 gen bölgesinde saptanan C607S mutasyonu.

Çalışmaya dahil edilen 49 hastanın 20 (\%40.8)'sinde CMV varyant sekans saptanmıştır. Toplamda 81 adet farklı varyant sekans saptanmış olup, üçü (A442G, C592F, A427V) daha önce yapılmış çalışmalarda tespit edilmiş, $78^{\prime} i$ ise ilk defa bu çalışmada elde edilmiştir.

Literatürde daha önce bildirilmeyen bu mutasyonlar; R434P, S472R, Y519N, D535Y, A590P, S431G, A442T, S483G, Q500H, H537Q, G544S, Y548F, S554T, Q614H, L426Q, A427E, P521R, V462G, R524Q, T504M, L532I, S512L, H513P, C518G, N492D, D422G, L484I, M550K, F523L, D430N, E486D, A538G, L528V, N558H, R434C, R506H, Q592H, L463I, A522T, L553V, A555S, A477V, G544A, A427G, D441V, R451G, H520P, A497V, A435P, H420Y, L545V, C453R, C511S, C518G, M526T, C598V, L515M, S438R, S485T, L556M, L560V, S485N, Y519S, A440T, L463V, V498I, R560H, L515M, W424R, C428G, V452R, F455C, P459T, R476C, Y482P, R494G, P525L olarak saptanmıştır. 


\section{TARTIŞMA}

CMV hastalığında antiviral ilaçlara direnç, genellikle birkaç haftalık antiviral tedavi sonrası ortaya çıkmaktadır. Yükselen CMV antijenemisi veya DNA seviyeleri, CMV hastalığı semptomlarının ilerlemesi, klinik veya viral dirence işaret etmektedir. Klinik direnç konak faktörüne, viral direnç ise viral genomdaki mutasyonlara bağlıdır ${ }^{4}$.

Çeşitli genotipik çalışmalarda GCV dirençli CMV klinik izolatlarında en yaygın UL97 mutasyonları saptanmış ve bu gen bölgesindeki GCV direnç mutasyonları 460, 520 ve 590-607 kodonlarında kümelenmiştir ${ }^{5}$. Bunların arasında en yaygın GCV direnç mutasyonu, M460V mutasyonudur ${ }^{2}$. Bir çalışmada, GCV dirençli klinik izolatların \%80'inde, yedi UL97 mutasyonundan en az biri (M460V, M460I, H520Q, C592G, A594V, L595S ve C603W) tespit edilmiştir6.

Hosseini ve arkadaşları, renal transplant alıcısı 58 hastada yaptıkları çalışmada ${ }^{7}, 10$ (\%17.2) hastada GCV direnç mutasyonu tespit etmişlerdir. Bu örneklerden dizi analizi yapılarak toplam 18 mutasyon saptanmış olup, bunların 16'sı UL97, ikisi UL54 gen bölgesi mutasyonudur.

Otuz pediatrik AKIT alıcısında yapılan bir çalışmada, UL97 gen bölgesinde GCV direnci bir hastada saptanmış, direnç mutasyonları ise M460V ile M460I olarak bulunmuştur ${ }^{8}$.

Kim ve arkadaşları, yapmış oldukları çalışmada ${ }^{9}$ pediatrik KiT hastalarında GCV direncini \%5.1 olarak bulmuşlardır. Bu çalışmada, pediatrik KiT alıcılarında \%5 oranında CMV antiviral direnç (C592G) mutasyonu saptanmıştır.

Zeytinoğlu ve arkadaşlarının çalışması ${ }^{10}$, Türkiye'de CMV UL97 gen bölgesinde GCV direncini araştıran ilk çalışma olup; biri renal transplant alıcısı (A594V), diğeri ise pediatrik KiT alıcısı olan iki hastada C603W mutasyonu saptanmıştır.

Çalışmamızda 49 hastanın 3 (\%6.1)'ünde antiviral direnç saptanmış olup, bu oran Delice ve arkadaşlarının çalışmasındaki ${ }^{11}$ antiviral direnç oranı (\%6.6) ile benzerlik göstermektedir.

Arslan ve arkadaşları, KiT alıCısı olup CMV ensefaliti gelişen bir olguda ${ }^{12}$, UL97 geninde M460V mutasyonu saptamışlardır.

Çalışmamızdaki KiT alıcısı erkek hastada (ikinci hasta) M460I mutasyonu saptanmıştır. Hastaya transplantasyon yapıldıktan sonra, CMV viral yük artışı devam etmiş olup, bunun M460I mutasyonunun yüksek düzey direnç oluşturmasından ileri geldiği düşünülmektedir. Chou ve Bowlin'in çalışmasında ${ }^{13}$, M460I mutasyonlu suşlarda, GCV ve siklopropavirin, $\mathrm{EC}_{50}$ değerinin \%10-20 kat üzerinde etkili olabildiği gösterilmiştir.

C592G mutasyonunun, diğer mutasyonlara göre düşük düzey GCV direnci oluşturduğu, ancak hastaya bağlı birtakım faktörlerin bu mutasyonun direnç geliştirmesine katkı sağladığı bildirilmiştir ${ }^{14}$. Çalışmamızda C592G mutasyonu saptanan birinci hastaya transplantasyondan sonra GCV tedavisi başlanması ve sonrasında FOS ve GCV tedavi- 
lerinin uzun dönem kullanılması, hastada "graft versus host hastalığı" gelişmesi direnç gelişiminde mutasyona eşlik eden faktörler arasında sayılabilir.

Konjenital CMV enfeksiyonu geçiren yenidoğanlarda yapılmış bir araştırmada, GCV direnç mutasyonu olarak saptanan M460V/I, C592G mutasyonlarının yanı sıra henüz fenotipik testlerle doğrulanmamış, ancak yeni bir mutasyon olarak kabul edilmiş C607S \%3.3 oranında bulunmuştur ${ }^{15}$. Çalışmamızda da üçüncü hastada C607S mutasyonu saptanmıştır.

Lopez-Aladid ve arkadaşlarının NGS tekniği kullanarak yapmış oldukları bir başka çalışmada ${ }^{16}$, Sanger tekniği ile mutasyonların daha düşük oranda saptandığı; NGS ile daha duyarlı sonuçlar elde edildiği belirtilmiştir. Aynı çalışmada 44 hastanın 12'sinde Sanger ile 14 (\%27) mutasyon saptanırken, NGS ile 16 hastada 20 (\%36) mutasyon bulunmuştur.

Garrigue ve arkadaşları ${ }^{17}$, böbrek transplant alıcılarında CMV GCV direncinin erken saptanması için UL97 gen bölgesindeki mutasyonları hem NGS hem de Sanger dizi analizi tekniği ile çalışmışlardır. NGS; UL97 L595S mutasyonunun daha alt popülasyonlarda dahi izolasyonuna izin verirken, Sanger tekniği ile sadece vahşi tip mutasyonlar belirlenebilmiştir.

Çalışmamızda Sanger yöntemi ile değerlendirilemeyen örnekler, NGS ile değerlendirilebilmiş ve sonuçlandırılmıştır. NGS tekniklerinin, Sanger tekniğine göre alt popülasyonları da saptayabilmesi, GCV direnci çalışmalarında daha duyarlı sonuçlar ortaya koymaktadır. Guermouche ve arkadaşlarının ultra derin sekanslama (UDS) tekniği kullanarak CMV antiviral direncini araştırdıkları bir çalışmada ${ }^{18}$, uzun süreli antiviral tedavi gören immün yetmezlikli hastalardan izole edilen CMV UL97 ve UL54 gen bölgelerinde minör ve majör varyant diziler saptanmış ve bu diziler, tedavi başarısızlığının bir nedeni olarak gösterilmiştir.

Bu çalışmada, literatürde bildirilen üç varyant sekans ile daha önce bildirilmemiş 78 adet varyant sekans saptanmıştır. Saptanan varyantların ilaç direncindeki rolünün belirlenmesi için fenotipik testlerin yapılması gerekmektedir ${ }^{1}$.

Klinisyenler hastaların tedavilerini planlarken, transplantasyonun zamanı, immünsupresyonun yoğunluğu ve tipi, UL97 mutasyonlarının sıklığı ve testlerin yorumlanmasını da içeren faktörler arasında dengeleyici kararlar vermelidir.

Sonuç olarak, antiviral direnç saptanması hastaların takibinde önemli olup, tedavinin planlanmasında klinisyeni yönlendirmektedir. Sanger yöntemi ile değerlendirilemeyen örneklerin NGS ile çalışılması gerektiği ve ilk defa saptanan varyant sekansların ilaç direncindeki rolünün belirlemesi için daha ileri çalışmalara gereksinim olduğu düşünülmektedir.

\section{ETIK KURUL ONAYI}

Bu çalışma, Erciyes Üniversitesi Klinik Araştırmalar Etik Kurulu onayı ile gerçekleştirildi (Tarih: 22.01.2016 ve Karar no: 2016/57).

\section{ÇIKAR ÇATIŞMASI}

Yazarlar bu makale ile ilgili herhangi bir çıkar çatışması bildirmemişlerdir. 
İmmün Yetmezlikli Hastalardan Elde Edilen Sitomegalovirüs

İolatlarındaki Gansiklovir Direncinin Araştırılması

\section{KAYNAKLAR}

1. Chen K, Cheng MP, Hammond SP, Einsele H, Marty FM. Antiviral prophylaxis for Cytomegalovirus infection in allogeneic hematopoietic cell transplantation. Blood Adv 2018;(16):2159-75.

2. Razonable RR. Drug-resistant Cytomegalovirus: clinical implications of specific mutations. Curr Opin Organ Transpl 2018;23(4):388-94.

3. Chaer FE, Shah DP, Chemaly RF. How I treat resistant Cytomegalovirus infection in hematopoietic cell transplantation recipients. Blood 2016;128(23):2624-36.

4. Razonable RR, Humar A. Cytomegalovirus in solid organ transplant recipients- guidelines of the American society of transplantation infectious diseases community of practice. Clin Transplant 2019;33(9):e13512.

5. Aslani HR, Ziaie S, Salamzadeh J, Zaheri S, Samadia F, Tehrani SM. Incidence of ganciclovir resistance in CMV-positive renal transplant recipients and its association with UL97 gene mutations. Iran J Pharm Res 2017;16(2):805-10.

6. Chou S, Ercolani RJ, Vanarsdall AL. Differentiated levels of ganciclovir resistance conferred by mutations at codons 591 to 603 of the Cytomegalovirus UL97 kinase gene. J Clin Microbiol 2017;55(7):2098-104.

7. Hosseini SM, Nemati E, Behzadian F, Einollahi B, Petrudy AR, Sohraby M, et al. Evaluation of ganciclovir resistance in Cytomegalovirus infection of renal transplant recipients in Tehran. Transplant Proc 2015;47(4):1140-2.

8. Arellano-Galindo J, Vázquez-Meraz E, Jiménez-Hernández E, Velazquez-Guadarrama N, Mikeler E, Hamprecht $\mathrm{K}$, et al. The role of Cytomegalovirus infection and disease in pediatric bone marrow transplant recipients in Mexico City in the context of viral drug resistance. Pediatr Transplant 2011;15(1):103-11.

9. Kim YJ, Boeckh M, Cook L, Stempel H, Jerome KR, Boucek R Jr, et al. Cytomegalovirus infection and ganciclovir resistance caused by UL97 mutations in pediatric transplant recipients. Transpl Infect Dis 2012;14(6):611-7.

10. Zeytinoğlu A, Turhan A, Keskinoglu A, Aksoylar S, Dincel N, Deveci B, et al. The first two ganciclovir resistant Cytomegalovirus isolates from kidney and pediatric stem cell transplant recipients in Turkey. J Immunol Clin Microbiol 2016;1(3):1-4.

11. Delice S, Gökahmetoğlu S, Kaynar L, Karakükcü M. Gansiklovir tedavisi alan immün yetmezlikli hastalarda, CMV UL54 ve UL97 gen bölgelerinde gansiklovir direncinin araştırılması. Mikrobiyol Bul 2015;49(3):393402.

12. Arslan F, Tabak F, Avşar E, Midilli K, Mert A, Ozaras R, et al. Ganciclovir-resistant Cytomegalovirus encephalitis in a hematopoietic stem cell transplant recipient. J Neurovirol 2010;16(2):174-8.

13. Chou S, Bowlin TL. Cytomegalovirus UL97 mutations affecting cyclopropavir and ganciclovir susceptibility. Antimicrob Agents Chemother 2011;55(1):382-4.

14. Choi SH, Hwang JY, Park KS, Kim Y, Lee SH, Yoo KH, et al. The impact of drug-resistant Cytomegalovirus in pediatric allogeneic hematopoietic cell transplant recipients: a prospective monitoring of UL97 and UL54 gene mutations. Transpl Infect Dis 2014;16(1):919-29.

15. Campanini G, Zavattoni M, Cristina E, Gazzolo D, Stronati M, Baldanti F. Multiple ganciclovir-resistant strains in a newborn with symptomatic congenital human Cytomegalovirus infection. J Clin Virol 2012;54(1):86-8.

16. Lopez-Aladid R, Guiu A, Mosquera M, Lopez-Medrano F, Cofan F, Linares L, et al. Improvement in detecting Cytomegalovirus drug resistance mutations in solid organ transplant recipients with suspected resistance using next generation sequencing. PloS ONE 2019;14(7):1-13.

17. Garrigue I, Moulinas R, Pinson-Recordon P, Delacour ML, Essig M, Kaminski H, et al. Contribution of next generation sequencing to early detection of Cytomegalovirus UL97 emerging mutants and viral subpopulations analysis in kidney transplant recipients. J Clin Virol 2016:80(1):74-81.

18. Guermouche H, Burrel S, Mercier-Darty M, Kofman T, Rogier O, Pawlotsky JM, et al. Characterization of the dynamics of human Cytomegalovirus resistance to antiviral drugs by ultra-deep sequencing. Antivir Res 2020;173:104647. 
